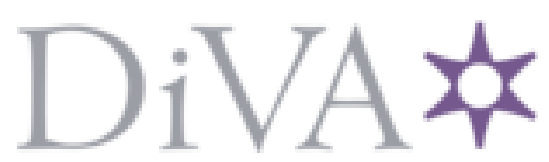

http://www.diva-portal.org

This is the published version of a paper published in Journal of Public Policy.

Citation for the original published paper (version of record):

Edlund, J., Lindh, A. (2013)

Institutional trust and welfare state support: onthe role of trust in market institutions.

Journal of Public Policy, 33(3): 295-317

http://dx.doi.org/10.1017/S0143814X13000160

Access to the published version may require subscription.

N.B. When citing this work, cite the original published paper.

Permanent link to this version:

http://urn.kb.se/resolve?urn=urn:nbn:se:umu:diva-81915 


\section{Journal of Public Policy}

http://journals.cambridge.org/PUP

Additional services for Journal of Public Policy:

Email alerts: $\underline{\text { Click here }}$

Subscriptions: $\underline{\text { Click here }}$

Commercial reprints: $\underline{\text { Click here }}$

Terms of use : $\underline{\text { Click here }}$

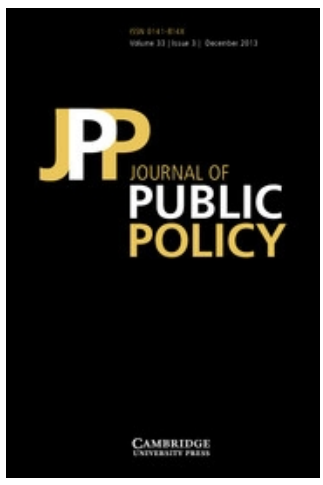

\section{Institutional trust and welfare state support: on the role of trust in market institutions}

Jonas Edlund and Arvid Lindh

Journal of Public Policy / Volume 33 / Issue 03 / December 2013, pp 295 - 317

DOI: 10.1017/S0143814X13000160, Published online: 10 October 2013

Link to this article: http://journals.cambridge.org/abstract_S0143814X13000160

How to cite this article:

Jonas Edlund and Arvid Lindh (2013). Institutional trust and welfare state support: on the role of trust in market institutions. Journal of Public Policy, 33, pp 295-317 doi:10.1017/S0143814X13000160

Request Permissions : $\underline{\text { Click here }}$ 


\title{
Institutional trust and welfare state support: on the role of trust in market institutions
}

\author{
JONAS EDLUND \\ Department of Sociology, Umeå University, Umeå, Sweden \\ E-mail: jonas.edlund@soc.umu.se \\ ARVID LINDH \\ Department of Sociology, Umeå University, Umeå, Sweden \\ E-mail: arvid.lindh@soc.umu.se
}

\begin{abstract}
The importance of institutional trust for structuring welfare state support (WSS) has been advanced by several scholars. Yet, the thesis has not received convincing empirical support. We argue that the weak evidence observed by previous research is caused by the failure of not extending the analytical framework beyond the study of public institutions. Using Sweden as a test case, our analytical framework covers trust in public institutions (TPI) and market institutions (TMI). The main findings are: (1) TMI has a robust negative effect on WSS; (2) the expected relationship between TPI and WSS is strengthened controlling for TMI; (3) TMI mediates the relationships between socio-economic variables and WSS. These findings underline the importance of bringing in other institutional configurations that are seen as conceivable alternatives to the state for administrating social welfare, not the least in studies primarily interested in the link between TPI and support for state-organised welfare.
\end{abstract}

Key words: attitudes, institutions, market, public, trust, welfare state

If people believe that government is incompetent and cannot be trusted, they are less likely to provide [critical] resources. Without critical resources, government cannot perform well, and if government cannot perform, people will become more dissatisfied and distrustful of it. Such a cumulative downward spiral could erode support for democracy as a form of governance (Nye et al. 1997, 4).

\section{Introduction}

Theoretical accounts such as the above - on the importance of trust in public institutions (TPI) for understanding variation in public support for 
state-organised welfare - have been advanced by several scholars (e.g. Rose 1991; Steinmo 1994; Rothstein 1998; Rothstein and Steinmo 2002). Compared with the amount of the literature theoretically describing the potentially detrimental effects of declining TPI on welfare state support (WSS), relatively few studies contain empirical applications on the subject. As described later in detail, the main message from these works is, rather surprisingly, that the theory does not receive convincing empirical support.

The main argument raised in this paper is that the institutional focus characterising previous research is too narrow. It is necessary to pay attention to citizens' trust in institutional configurations perceived as conceivable alternatives to the state for organising and producing social welfare. Using Sweden as a strategic test case, we argue that trust in the obvious counterpart to the state - the market and its actors - may have more to do with citizens' support of state-led welfare policies than their TPI.

In this study, we focus specifically on the link between trust in market institutions (TMI) and support for state-organised welfare. We suggest that support for the welfare state is not only affected by citizens' conceptions of what the state can do but also by citizens' conceptions of what markets cannot do. We hypothesise that, once this awareness is integrated in the analytical framework, a distinct relationship between institutional trust and WSS should become apparent.

Methodologically, the hypothesis is tested with structural equation modelling (SEM). The data consist of a nationally representative sample of Swedes aged 18-79 collected in 2010. Our dependent variables deal with public support for two cornerstones of the ideal-typical Scandinavian welfare state: the financing and the provision of social services. Our measurements of institutional trust are constructed from assessments of perceived institutional performance.

The basic characteristics of Swedish welfare policy and its recent political history make it a particularly interesting case for juxtaposing trust in state and market when exploring the link between institutional trust and WSS. Somewhat crudely put, in the public mind of Swedes, the two dominant institutional alternatives that have the capacity to administer a large-scale welfare services apparatus are the state on the one hand, and firms operating in the market on the other hand. Other actors, such as the family, cooperatives, religious and charity organisations, have in the Swedish context not been seen as realistic alternatives, except for childcare, where small segments of the citizenry prefer the family and cooperatives (Johansson Sevä 2010).

The paper is structured as follows. First, we spell out the theoretical arguments and review the relevant literature. Then data, measurements 
and statistical methods are discussed. This is followed by the empirical section. In the first step, we model the relationships between trust in public and market institutions and their socio-economic determinants. In the second step, the impact of each of the institutional trust variables on WSS is estimated. The concluding section restates the main findings and the implications for future research are discussed.

\section{Theory: welfare regimes, institutional trust and welfare state support}

The institutional configuration of a particular society and political community can be conceived of as a specific balance between the complementary institutional logic of state, market and civil society. Such configurations vary greatly across countries, giving rise to different "welfare regimes" and "varieties of capitalism" (Esping-Andersen 1990; Hollingsworth and Boyer 1997; Hall and Soskice 2001).

A distinguished feature of the Nordic type of welfare regime - setting it apart from other high-spending welfare states - is its mainly tax-funded and publicly provided social service system (Sipilä 1997; Daly and Lewis 2000; Rauch 2007). In Sweden, citizens, to a larger extent than in most other countries, have come to rely on the state - rather than the market or civil society - for their social welfare. Yet there has been considerable change in Swedish welfare policy during the most recent decades. First, there have been substantive cutbacks in the generosity of social insurance programmes (Ferrarini et al. 2012). Second, although the financing of the welfare service apparatus in Sweden is still predominantly tax based, there is an ongoing trend of increased privatisation of welfare service production across a range of policy areas such as child care, elderly care, health care and, in particular, primary and secondary schooling (Blomqvist and Rothstein 2000; Trydegård 2001; Blomqvist 2004; Bergh 2007; Hartman 2011). The privatisation of secondary schooling highlights this trend: about 20 per cent of Swedish secondary school pupils attended an independent school in 2010 compared with about 2 per cent in 1996. The share of employees in private firms working in the welfare service sector equally amounts to about 20 per cent today. ${ }^{1}$

A common approach in studies on the role of institutional trust for WSS is to start with a variant of the following claim: in order for people to be willing to handover tasks and resources to public institutions, citizens need to perceive these institutions as fair, impartial and efficient

${ }^{1}$ Civil society/third sector institutions play a subordinate role in modern-day Swedish welfare policy model. Political struggles and reform during the most recent decades have mainly been about altering the institutional balance between the state and the market. 
(Steinmo 1994; Nye et al. 1997; Rothstein 1998; Svallfors 2012). The basic idea is that perceptions of public institutions as trustworthy and high performing transform into support for state-organised welfare, whereas distrust in public institutions is supposed to be manifested in negative attitudes about the role of the state for administering social welfare. Previous research exploring this hypothesis has both dealt with trust in political decisionmaking institutions and specific welfare policy institutions, covering single countries (Blomberg 1999; Gevers et al. 2000; Edlund 2006; Calzada and del Pino 2008), small-scale country comparisons (Edlund 1999; Svallfors 2002) and large-scale European comparisons (Kumlin 2007a; Blomberg et al. 2012; Svallfors 2012; Van Oorschot and Meuleman 2012). Among these works, we find studies reporting positive correlations (Blomberg et al. 2012; Svallfors 2012), negative correlations (Blomberg 1999; Calzada and del Pino 2008; Van Oorschot and Meuleman 2012) and those reporting mixed or insignificant relationships (Edlund 1999, 2006; Gevers et al. 2000; Svallfors 2002; Kumlin 2007a). The collective evidence of previous research is thus relatively disappointing for the trust thesis; only a small minority of previous works finds distinct relationships significantly deviating from the null hypothesis in the expected direction.

We believe, on balance, that the weak empirical evidence in favour of the trust thesis is rooted in the limited scope of previous research - both in theory and in empirical applications - by narrowing down the analytical focus to the study of TPI only, failing to take into consideration citizens' trust in other institutional constructs than the state. As welfare policies shape the balance between state, market and civil society as complementary institutional logics, welfare policy preferences express public opinions about the proper balance between multiple institutional domains. We therefore propose that welfare policy preferences are not only influenced by TPI, but also by trust in institutional configurations that make up conceivable alternatives to the state for administering and allocating social welfare.

This article uses Sweden as a strategic test case. The Swedish welfare model is currently undergoing considerable institutional change in the direction of more market-based solutions at the expense of less state-organised welfare. To test our hypothesis in such a context, it seems appropriate to focus on two sets of institutions: public and market (Esping-Andersen 1985). As pointed out above, there are good reasons assuming that the market is perceived by citizens (with favour or disfavour) as the main institutional alternative to the state within the sphere of social welfare. ${ }^{2}$

${ }^{2}$ We think that expanding the analytical framework by including both market and public institutions is sufficient for testing the thesis in the Swedish context. We are well aware that if we were to test the hypothesis in a different country context, we might have had to bring in 
As pointed out above, previous works dealing with the links between institutional trust and WSS has not integrated TMI within the theoretical framework and hence not subjected it to empirical analyses. Yet, the theoretical arguments for expecting TMI to affect WSS are relatively straightforward.

First, state-organised welfare is typically understood as a political instrument for making citizens' social welfare less dependent on market relationships and market institutions (Esping-Andersen 1985, 1990). Consequently, welfare policy preferences are typically understood as expressions of conceptions of the extent to which the state should intervene in the market economy and its distributive outcomes, or in other words, conceptions of what the proper institutional balance between the state and the market ought to be like (Kumlin 2007b). Preferences for state-organised welfare are thus likely to be a function of trust both in the state and the market. Similar to institutional theory, which suggests that higher TPI should generate greater WSS, we argue that greater TMI should lower WSS by nourishing a stronger preference for market-organised welfare.

Second, the market dimension is a key factor in understanding why individuals in more favourable socio-economic positions are typically less supportive of state-organised welfare compared with individuals in less favourable positions (Svallfors 2006). The main reason why labour market stratification, that is, social class, is a central mechanism explaining variation in WSS is because of the unequal distribution of resources and risks that different classes carry to the market. Thus, market-based experiences are central to the structuring of WSS.

Third, our analytical approach is informed by previous research demonstrating a positive trust correlation across different institutional domains. On average, those having greater TPI also have greater TMI (Lipset and Schneider 1983; Uslaner 2010; Holmberg and Weibull 2012). This is an important finding for two reasons. First, it shows that the relationship between conceptions of state and market is not necessarily manifested in a conflict relationship, that is, a negative correlation. Hence, it is not self-evident that the expected negative relationship between TMI and WSS will receive empirical support. Second, when studying the relationships between TPI and WSS, the overall positive trust correlation across institutional domains suggests that it is important to control for TMI.

other dimensions of institutional trust to test our claims. Moreover, we want to clarify that the aim of this study is not to account for the link between institutional trust and welfare state support in its full complexity. If we were to embark on such a journey, we would most certainly have to take into consideration additional dimensions of institutional trust. 


\section{Data, measurements and method}

\section{Data}

The data come from the Swedish Welfare State Survey 2010. The sample is nationally representative of Swedes aged $18-79(n=3804) .{ }^{3}$ This data set contains items on trust in public and market institutions, as well as multiple batteries on welfare policy attitudes. In particular, we want to stress the value of having sophisticated measures covering TMI, as measures of this kind are not found in other comparable data sets. We also find it gratifying to be able to use different measurements of WSS, thereby allowing us testing the robustness of our approach, that is, to check the extent to which the conclusions are drawn are invariant of which particular measure of WSS is used.

\section{Measurements}

Institutional theory suggests that the normative feedback effects of perceived institutional performance on public opinion are likely to be most pronounced in areas where institutions have a recurrent presence in citizens' everyday life (Kumlin 2004; Svallfors 2012). When it comes to the measurements of WSS and TPI, we focus on the welfare services that most citizens come into contact with on a regular basis: health care, care of the elderly, child care and education. Our dependent variables of WSS capture the financing and provision of state-organised welfare. The measurement of TPI focuses on the perceived performance of the public sector in administrating these welfare services successfully.

The measurement of TMI is developed against the notion that business firms are powerful actors in public life, with major impact on the authoritative allocation and administration of a society's values and recourses (Crane et al. 2008; Crouch 2011). Business firms are components of the market sphere, which citizens come into direct contact with on a regular basis in their everyday life. Conceptions of business firms are likely to be decisive for people's understanding of market institutions in general, and we propose to measure TMI by asking for people's conceptions of business firm performance in embracive terms. How the "performance" of market actors should be conceptualised (both individually and in the aggregate) is in itself a contested subject. Following Wright (2004), we use a "comprehensive economic performance" approach. This perspective stresses that evaluations

3 The response rate was 57 per cent. An analysis of non-responses shows the following. For gender and region, differences in responses are negligible. For age, the young (old) are slightly under- (over-)represented in the sample. For further descriptions of non-responses, see Johansson Sevä (2010). 
of performance are not only to be restricted to assessments of whether profit levels are maximised within an economy, but should also consider the extent to which other valued outcomes are realised, such as job creation, societal development, refinement of human capital and so on. Such parameters are likely to be of the most immediate concern to a random individual within the population when evaluating performance.

In Table 1, six multi-indicator batteries are shown. The first battery asks the respondent about the perceived performance of various public sector services. As shown, a vast majority of Swedes tends to evaluate public welfare institutions in positive terms, especially when asked about the performance of child care, whereas the area with the most negative evaluations is care for the elderly. The second battery asks the respondent to evaluate the performance of firms across a range of issues. A majority of Swedes agree that firms in general perform well regarding prices, job creation, working conditions and, in particular, adaptation to new technology. In both batteries I and II, response distributions are biased towards positive evaluations rather than negative. However, the distributions are not particularly skewed.

The remaining four batteries measure WSS in the areas of education, health care, child care and care of the elderly. Battery III is about the form of financing for these services. Two alternatives are available: "Should as now mainly be financed through taxes" or "Should to a larger extent be financed through specific fees paid by those using the services" (italics added). As shown, a vast majority of Swedes prefers a collective financing via taxes, although about 20 per cent prefer a stronger element of private financing with respect to education and child care. Battery IV is also about financing, but focuses on individual willingness to pay higher taxes if the money is spent on welfare services. It is evident that a majority of Swedes are willing to increase their tax contribution under such circumstances, although the willingness to support families with children is comparatively lower. Battery $\mathrm{V}$ measures preferences for financing more generally: asking the respondent whether the amount of taxes used for different services should: "increase, remain unchanged, or decrease". The results for these items clearly show that most people choose either the increase or remain unchanged options. Battery VI is about the provision of welfare services and the respondent is asked to indicate which institutional actor - public agencies or private firms - is best suited for managing the different services. As shown in the table, most citizens prefer that these services are provided by the public sector, but there is some variation across the areas. Support for private firms as service providers is strongest for child care (20 per cent) and lowest for education (10 per cent). 


\section{Table 1. Indicators of institutional trust and welfare state support ordered by topic (Per cent)}

I. Trust in Public Institutions: TPI

\begin{tabular}{lcccc}
\hline $\begin{array}{l}\text { To what extent do you think that the public sector } \\
\text { in Sweden manages to: }\end{array}$ & $\begin{array}{c}\text { Very large } \\
\text { extent }\end{array}$ & $\begin{array}{c}\text { Large } \\
\text { extent }\end{array}$ & $\begin{array}{c}\text { Small } \\
\text { extent }\end{array}$ & $\begin{array}{c}\text { Very small } \\
\text { extent }\end{array}$ \\
\hline $\begin{array}{l}\text { a. Provide people that are sick with the health } \\
\quad \text { care that they need }\end{array}$ & 18 & 55 & 20 & 6 \\
$\begin{array}{l}\text { b. Provide good care for the elderly } \\
\text { c. Provide good child care } \\
\text { d. Provide children and youth with a good } \\
\quad \text { education }\end{array}$ & 9 & 42 & 35 & 10 \\
\end{tabular}

\section{Trust in Market Institutions: TMI}

\begin{tabular}{lcccc}
\hline $\begin{array}{l}\text { To what extent do you think that private firms } \\
\text { in general actually: }\end{array}$ & $\begin{array}{c}\text { Very large } \\
\text { extent }\end{array}$ & $\begin{array}{c}\text { Large } \\
\text { extent }\end{array}$ & $\begin{array}{c}\text { Small } \\
\text { extent }\end{array}$ & $\begin{array}{c}\text { Very Small } \\
\text { extent }\end{array}$ \\
\hline $\begin{array}{l}\text { e. Offers reasonable prices on goods and services } \\
\text { f. Turn business opportunities into job opportunities }\end{array}$ & 7 & 55 & 32 & 6 \\
g. Offer favourable terms of employment for & 6 & 50 & 36 & 6 \\
$\quad \begin{array}{l}\text { employees } \\
\text { h. Adapts its enterprise to new knowledge and } \\
\quad \text { technology }\end{array}$ & 16 & 68 & 33 & 2 \\
\hline
\end{tabular}

III. Welfare State Support: Finform

\begin{tabular}{|c|c|c|}
\hline $\begin{array}{l}\text { How do you think that these } \\
\text { activites should be financed: }\end{array}$ & $\begin{array}{c}\text { Should as now } \\
\text { mainly } \\
\text { Be financed through } \\
\text { taxes }\end{array}$ & $\begin{array}{c}\text { Should to a larger extent } \\
\text { be financed } \\
\text { Through specific } \\
\text { fees paid by users }\end{array}$ \\
\hline i. Health services & 95 & 5 \\
\hline j. Care for the elderly & 93 & 7 \\
\hline k. Child care & 78 & 22 \\
\hline 1. Education & 81 & 19 \\
\hline
\end{tabular}

\section{Welfare State Support: Taxwill}

Are you personally willing to pay more in tax if the money went to any of the following areas:

$\begin{array}{cccc}\text { Yes, } & \text { Yes, } & \text { No, } & \text { No, } \\ \text { absolutely } & \text { probably } & \text { probably not } & \text { definitely not }\end{array}$

m. Health care

$\begin{array}{lll}36 & 42 & 17\end{array}$

n. Support for the elderly

o. Support to families with children

p. Schools (customary and high school)
31

15

32
17

19

36

20
6

6

11

6 


\section{Table 1 (Continued)}

V. Welfare State Support: Spending

Taxes are utilised for different aims. Do you think

that the amount of taxes being utlised for these aims

should increase, remain unchanged, or decrease:

Increase Unchanged Decrease

\begin{tabular}{llll}
\hline q. Health services & 67 & 31 & 2 \\
r. Care for the elderly & 72 & 26 & 2 \\
s. Child care & 29 & 63 & 8 \\
t. Education & 62 & 37 & 1 \\
\hline
\end{tabular}

VI. Welfare State Support: Provider

\begin{tabular}{lcc}
\hline $\begin{array}{l}\text { Who is best suited to provide the following } \\
\text { welfare services: }\end{array}$ & $\begin{array}{c}\text { Private } \\
\text { firms }\end{array}$ & 14 \\
\hline u. Health services & 86 & 16 \\
v. Care for the elderly & 84 & 20 \\
x. Child care & 80 & 10 \\
y. Education & 90 & \\
\hline \hline
\end{tabular}

Source: Swedish Welfare State Survey (2010).

In the following analysis, a number of socio-economic variables (social class, age, gender, sector of employment) are included for two reasons. First, they are assumed to be important for explaining variation in WSS. When examining relationships between institutional trust and WSS, it seems warranted to bring them in as control variables. Second, it is theoretically interesting to examine the extent to which institutional trust is a mediating factor, linking social position to preferences for stateorganised welfare. Although it is well-known from previous research that socio-economic groups less well-off in the labour market are more supportive of state-organised welfare, we also find it likely that individuals with less marketable resources and higher risks to carry within the labour market develop less TMI compared with those better off in terms of risks and resources. Therefore, we find it interesting to explore whether social groups that are more (less) supportive of the welfare state are so because they have less (more) trust in the market and its principal actors. We expect that the more privileged classes, men and those in prime age express higher levels of TMI compared with workers, women, the young and the elderly. We would, however, underline that class is believed to be the most important indicator of socio-economic position in this respect. In addition, emphasising processes of selection and tertiary (i.e. sectorspecific) socialisation, we also expect that those employed in the private 
sector have more TMI compared with public employees (Korpi 1983; Esping-Andersen 1985, 1993; Hernes 1987; Hoel and Knutsen 1989; Orloff 1993).

Gender and sector of employment are dichotomous variables (men/ women; public/private). For age, respondents are divided into four age groups. Social class is measured by the six-category version of the EGP class schema (Erikson and Goldthorpe 1992).

\section{Method}

Methodologically, we apply SEM (Mplus 5.0 software), and it is assumed that each battery (I-VI) of the manifest indicators in Table 1 can be represented by a latent variable. Confirmatory factor analysis (CFA) is a basic ingredient of SEM. When estimating a latent variable, CFA uses the co-variation between a set of manifest indicators. The variance part in each indicator that is unrelated to the latent variable is excluded from it, a procedure that reduces measurement error and makes the SEM approach more appropriate compared with the common additive index of manifest indicators' approach. In addition, within the SEM framework, it is possible to model the structural relationships between multiple latent variables in a rigorous manner (Brown 2006; Schumacker and Lomax 2010).

As the survey indicators are ordinal and with few categories (binary in some cases), the analyses are performed with weighted least squares means and variance-adjusted (WLSMV) estimation (Muthén et al. 1997; Flora and Curran 2004; Beauducel and Herzberg 2006). When evaluating model fit, we judge an acceptable model fit as demonstrating a minimum value of $0.05-0.08$ for the root mean square error of approximation (RMSEA) measure, and a minimum value of 0.90-0.95 for the comparative fit index (CFI) (Hu and Bentler 1999; Marsh et al. 2004; Davidov et al. 2011).

Table 2 displays model fit measures from CFA carried out for each survey battery, respectively. The model fit statistics provide rather strong empirical support in favour of the assumption that each battery of items can be represented by a latent continuous variable. ${ }^{4}$

${ }^{4}$ An assumption within the SEM framework is that the residual variance of each indicator (i.e. the variance in a single indicator not covered by the latent variable) is randomly distributed and uncorrelated with the residual variance of the other indicators. This is not always a realistic assumption as survey batteries often pick up multiple attitude dimensions. Initial analysis demonstrated that for a number of the survey batteries we study (I, II, IV), this assumption is not true. We therefore allow for error correlations between certain specific indicators to be able to arrive at acceptable model fits. Moreover, if error correlations are allowed in the model, they should make sense from a theoretical point of view. The error correlations between " $\mathrm{c}-\mathrm{d}$ " and "o-p" are likely to capture a latent dimension related to the specific social welfare of 
Table 2. Model fit statistics for the measurement model of six latent variables

\begin{tabular}{lccccc}
\hline \hline & Battery & Items & CFI & RMSEA & Error corr. \\
\hline Trust in public institutions: TPI & I & a-d & 1.000 & 0.009 & $\mathrm{c}-\mathrm{d}$ \\
Trust in market institutions: TMI & II & $\mathrm{e}-\mathrm{h}$ & 0.998 & 0.058 & $\mathrm{f}-\mathrm{h}$ \\
Welfare state support: Finform & III & i-l & 0.975 & 0.071 & \\
Welfare state support: Taxwill & IV & $\mathrm{m}-\mathrm{p}$ & 0.999 & 0.082 & $\mathrm{o}-\mathrm{p}$ \\
Welfare state support: Spending & V & $\mathrm{q}-\mathrm{t}$ & 0.981 & 0.075 & \\
Welfare state support: Provider & VI & $\mathrm{u}-\mathrm{y}$ & 0.995 & 0.050 & \\
\hline \hline
\end{tabular}

Confirmatory Factor Analysis with WLSMV estimator.

Source: Swedish Welfare State Survey (2010).

Finally, there is the issue of causality. As our data are cross-sectional, we are unable to empirically settle the causal direction between institutional trust and WSS. When considering the results in the upcoming empirical analysis, the reader should bear in mind that the analytical design assumes that institutional trust has an impact on WSS rather than the other way around.

\section{Results}

The empirical test is conducted in two steps. First, we explore the relationships between the two dimensions of institutional trust and the extent to which the socio-economic variables have an impact on each one of them. In the second part, we focus on the relationships between institutional trust and WSS.

\section{Step 1: The relationships between TMI and TPI and their socio-economic determinants}

Figure 1 illustrates the SEM design. Two latent variables are estimated: one covering TPI on the basis of items a-d (illustrated by one box for each item), and one covering TMI on the basis of items e-h. Both constructs are specified as in Table 2 (latent variables I and II). ${ }^{5}$ The two latent variables TMI and TPI are allowed to correlate with each other.

young people. We interpret the error correlation " $\mathrm{f}-\mathrm{h}$ " as representing a specific latent dimension concerning the "innovative capacity" of business firms.

${ }^{5}$ The error correlations between specific indicators $(\mathrm{c}-\mathrm{d} ; \mathrm{f}-\mathrm{h})$ are not shown to keep the figure tolerably uncluttered. 


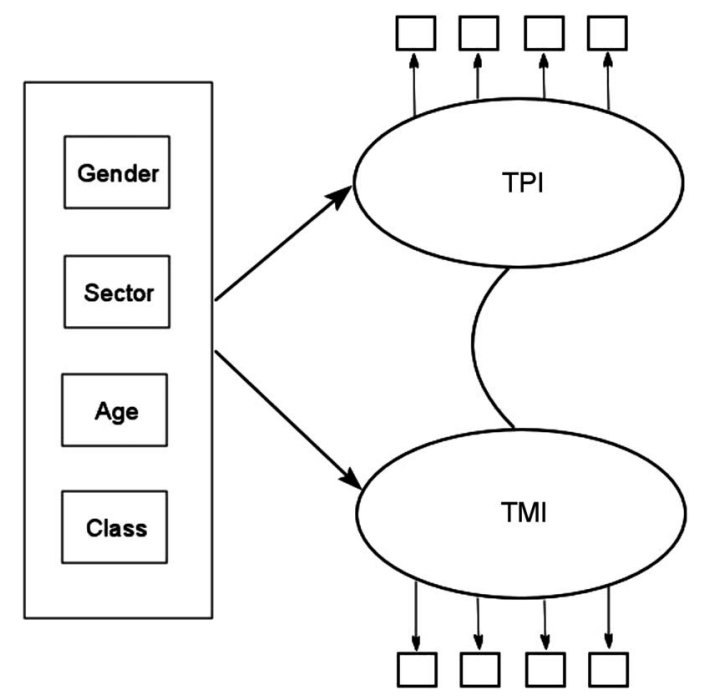

Figure 1 Illustration of the step 1 SEM design.

In addition, the socio-economic variables are allowed to influence the TMI and TPI variables.

Table 3 presents the results of the analysis. The fit statistics indicate that the model adequately represents the data. The model estimates a positive statistically significant correlation between TMI and TPI (0.17). On the one hand, the relatively weak correlation suggests that citizens tend to conceive the state and the market as separate institutional configurations, evaluating the performance of each institutional setting relatively independent from each other. On the other hand, it should be underlined that the positive and significant correlation indicates that citizens who trust the state are also somewhat more inclined to trust the market. This finding suggests that controlling for TMI may be important when exploring the relationship between TPI and WSS.

The effects of the socio-economic variables on institutional trust are shown in the form of unstandardised coefficients (b) and standardised coefficients $(\beta)$. When it comes to gender, we find that men are somewhat more trustful of public institutions compared with women, whereas there are no gender differences with respect to TMI. Turning to the sector of employment, results are as expected. Public sector employees have more TPI than private sector employees, and for TMI a reversed relationship can be observed. For age, it seems that the young trust market institutions to a greater extent than other age groups, and when it comes to TPI it seems that the elderly are more trustful compared with the other age groups. 
Table 3. The effects of socio-economic variables on trust in public and market institutions

\begin{tabular}{|c|c|c|c|c|}
\hline & \multicolumn{2}{|c|}{ TPI (I) } & \multicolumn{2}{|c|}{ TMI (II) } \\
\hline & $b$ & $\beta$ & $b$ & $\beta$ \\
\hline \multicolumn{5}{|l|}{ Gender $($ Woman $=0)$} \\
\hline Men & 0.08 & 0.16 & -0.01 & -0.02 \\
\hline \multicolumn{5}{|l|}{ Sector $($ Public $=0)$} \\
\hline Private & -0.10 & -0.20 & 0.14 & 0.19 \\
\hline \multicolumn{5}{|l|}{ Age $(65-79=0)$} \\
\hline $18-29$ & -0.21 & -0.38 & 0.18 & 0.21 \\
\hline $30-49$ & -0.20 & -0.40 & 0.07 & 0.11 \\
\hline $50-64$ & -0.18 & -0.35 & -0.07 & -0.11 \\
\hline \multicolumn{5}{|c|}{ Class (Unskilled manual worker $=0$ ) } \\
\hline Skilled Manual worker & -0.05 & -0.11 & -0.17 & -0.25 \\
\hline Routine non-manual worker & -0.02 & -0.05 & 0.14 & 0.19 \\
\hline Lower Service class & -0.03 & -0.04 & 0.29 & 0.40 \\
\hline Higher Service class & -0.04 & -0.07 & 0.34 & 0.48 \\
\hline Self-employed & -0.02 & -0.03 & 0.51 & 0.68 \\
\hline$R^{2}$ & \multicolumn{2}{|c|}{0.039} & \multicolumn{2}{|c|}{0.088} \\
\hline Correlation TPI-TMI & \multicolumn{4}{|c|}{0.17} \\
\hline Measures of model fit & \multicolumn{4}{|c|}{$\mathrm{CFI}=0.986 ; \mathrm{RMSEA}=0.025$} \\
\hline
\end{tabular}

Statistically significant parameters $(\alpha=0.05)$ on the basis of the unstandardised estimates are printed in bold.

Source: Swedish Welfare State Survey (2010).

Notes: Structural equation modelling with WLSMV estimator.

For social class, we note that its impact differs across the two trust dimensions. TMI is clearly related to class position. The more privileged groups - the self-employed and the service classes - express much stronger TMI compared with workers. This result confirms our theoretical expectations, namely, that those in less favourable market positions evaluate the performance of the market in less positive terms compared with those in more favourable positions. Class differences with respect to public institutions are, in contrast, negligible. A possible explanation for this result - that labour market position does not have an impact on TPI - is the universal character of the Swedish welfare state. The individual's citizen-state relationship is largely independent of her/his class position. ${ }^{6}$

${ }^{6}$ For further reading on the universal character of the Swedish welfare model, see for example: Korpi and Palme (1998, 2003), Huber and Stephens (2001), Scruggs (2006). 
As noted above, it is well known from previous research that the more privileged classes demonstrate less WSS compared with the less privileged classes. By adding the present finding that the more privileged classes also seem to trust market institutions to a greater extent compared with the less privileged, an interesting issue to explore in the next step of the analysis is whether the relationships between social class and WSS are affected by bringing in TMI in the model.

Before that, however, it is also worth noting the weak correspondence of socio-economic group differences across the two dimensions of trust. Despite the positive, albeit weak, correlation observed between the two dimensions of institutional trust, none of the socio-economic variables identifies specific groups demonstrating above-average levels of trust (or distrust) within both dimensions. Moreover, a trade-off in trust across the two spheres is found only with respect to the sector of employment. This finding further strengthens the argument that expressions of trust in the state and the market are shaped relatively independent of each other.

\section{Step 2: Modelling the impact of institutional trust on WSS}

In this section, the relationships between institutional trust and WSS are subjected to analysis. For WSS, we use the four different constructs shown in Table 2 (latent variables III-VI). The estimated models can be understood as extended models of the step 1 SEM design, as a latent WSS variable is added to the previous model design (see Figure 2).

For each of the four WSS measures, two models are estimated. In the first model, all effects of TMI are constrained to zero, thereby allowing us to replicate the model output that would have been generated if the analytical framework characterising previous research had been adopted, that is, to measure the strength of an expected positive correlation between TPI and WSS. In the second model, the restrictions of the TMI variable are relaxed; both the TPI and TMI variables are allowed to influence the WSS variable. This procedure enables us to evaluate whether the multi-dimensional approach of the second model better represents the data compared with the one-dimensional approach adopted by previous research in depicting the links between institutional trust and support for the welfare state.

The procedure is technically modelled by the correlation between the two trust variables and the assumed causal effect of TMI on the dependent variable being constrained to zero in the first model (indicated by dotted lines in the figure), whereas in the second model these two relationships are estimated. The first model is thus more restricted, and as it is nested within the second model it is possible to compare them in terms of model fit. 


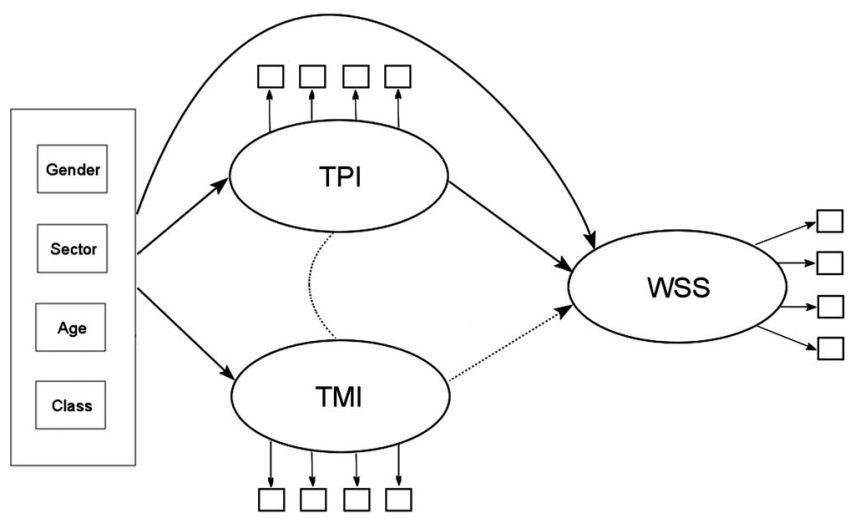

Figure 2 Illustration of the step 2 SEM design.

Apart from model fit statistics, of special interest when comparing these two types of models is the search for possible mechanisms explaining relationships between socio-economic variables and support for the welfare state. By examining the extent to which the effects of the socio-economic variables on WSS change when TMI is estimated in the model, we may get an understanding about the role of market experiences for shaping different social groups' welfare policy preferences, an issue that is an important part of the theoretical construct in class theories (Korpi 1983; Esping-Andersen 1990; Korpi and Palme 2003; Svallfors 2006).

Table 4 shows the results for two models for each of the four dependent WSS variables, in the form of unstandardised and standardised coefficients. $^{7}$ The scale for the dependent variables goes from low to high WSS. We will begin by reporting the results for the more restricted model $1 .^{8}$ Focusing specifically on the TPI-WSS link, the expected positive relationship can be observed in three out of the four models (1A [Finform], 1B [Taxwill], 1D [Provider]). However, for model 1C [Spending], we can witness a negative relationship, suggesting that those trusting public institutions are less willing to increase social spending compared with those distrusting public institutions.

${ }^{7}$ It should be noted that the standardised coefficients are calculated differently for latent variables and manifest covariates. Therefore, the standardised effects of latent variables and covariates are not directly comparable (Muthén and Muthén, 2007, 577-579).

${ }^{8}$ The causal effects of the socio-economic variables on each institutional trust were covered in the first step of analysis, see Table 3. While these relationships are estimated in this model too, they are for parsimonious reasons not shown in Table 4. 
Table 4. The effects of institutional trust and socio-economic variables on welfare state support

\begin{tabular}{|c|c|c|c|c|c|c|c|c|c|c|c|c|c|c|c|c|}
\hline & \multicolumn{4}{|c|}{ Finform (III) } & \multicolumn{4}{|c|}{ Taxwill (IV) } & \multicolumn{4}{|c|}{ Spending $(\mathrm{V})$} & \multicolumn{4}{|c|}{ Provider (VI) } \\
\hline & \multicolumn{2}{|c|}{ Model 1A } & \multicolumn{2}{|c|}{ Model 2A } & \multicolumn{2}{|c|}{ Model 1B } & \multicolumn{2}{|c|}{ Model 2B } & \multicolumn{2}{|c|}{ Model 1C } & \multicolumn{2}{|c|}{ Model 2C } & \multicolumn{2}{|c|}{ Model 1D } & \multicolumn{2}{|c|}{ Model 2D } \\
\hline & $\mathrm{b}$ & $\beta$ & $\mathrm{b}$ & $\beta$ & $\mathrm{b}$ & $\beta$ & $\mathrm{b}$ & $\beta$ & $\mathrm{b}$ & $\beta$ & $\mathrm{b}$ & $\beta$ & $\mathrm{b}$ & $\beta$ & $\mathrm{b}$ & $\beta$ \\
\hline TPI (I) & 0.08 & 0.08 & 0.10 & 0.10 & 0.13 & 0.07 & 0.18 & 0.10 & -0.21 & -0.13 & -0.19 & -0.11 & 0.27 & 0.21 & 0.35 & 0.27 \\
\hline TMI (II) & 0.00 & 0.00 & -0.07 & -0.09 & 0.00 & 0.00 & -0.21 & -0.16 & 0.00 & 0.00 & -0.14 & -0.12 & 0.00 & 0.00 & -0.35 & -0.37 \\
\hline \multicolumn{17}{|l|}{ Gender $($ Woman $=0$ ) } \\
\hline Men & -0.05 & -0.10 & -0.05 & -0.10 & -0.03 & -0.04 & -0.04 & -0.04 & -0.20 & -0.26 & -0.21 & -0.26 & -0.02 & -0.02 & -0.03 & -0.04 \\
\hline \multicolumn{17}{|l|}{ Sector $($ Public $=0)$} \\
\hline Private & -0.05 & -0.08 & -0.03 & -0.06 & -0.19 & -0.20 & -0.16 & -0.16 & -0.18 & -0.22 & -0.16 & -0.20 & -0.23 & -0.34 & -0.17 & -0.26 \\
\hline \multicolumn{17}{|l|}{ Age $(65-79=0)$} \\
\hline $18-29$ & 0.02 & 0.03 & 0.03 & 0.06 & -0.07 & -0.06 & -0.03 & -0.03 & -0.21 & -0.24 & -0.18 & -0.21 & -0.22 & -0.29 & -0.14 & -0.18 \\
\hline $30-49$ & 0.03 & 0.06 & 0.04 & 0.06 & 0.15 & 0.17 & 0.18 & 0.19 & -0.04 & -0.04 & -0.02 & -0.02 & -0.13 & -0.19 & -0.09 & -0.13 \\
\hline $50-64$ & 0.03 & 0.04 & 0.02 & 0.04 & 0.20 & 0.22 & 0.19 & 0.20 & 0.00 & 0.00 & -0.01 & 0.00 & 0.03 & 0.04 & 0.02 & 0.04 \\
\hline \multicolumn{17}{|c|}{ Class (Unskilled manual worker $=0$ ) } \\
\hline Skilled Manual worker & 0.09 & 0.18 & 0.08 & 0.18 & 0.13 & 0.14 & 0.09 & 0.11 & 0.14 & 0.18 & 0.12 & 0.14 & 0.07 & 0.11 & 0.02 & 0.04 \\
\hline Routine non-manual worker & 0.05 & 0.09 & 0.06 & 0.09 & -0.05 & -0.05 & -0.02 & -0.02 & -0.11 & -0.14 & -0.09 & -0.12 & -0.07 & -0.12 & -0.02 & -0.02 \\
\hline Lower Service class & 0.06 & 0.13 & 0.08 & 0.16 & -0.18 & -0.20 & -0.12 & -0.13 & -0.25 & -0.31 & -0.21 & -0.27 & -0.19 & -0.29 & -0.09 & -0.13 \\
\hline Higher Service class & -0.01 & -0.03 & 0.01 & 0.03 & -0.29 & -0.31 & -0.21 & -0.24 & -0.39 & -0.52 & -0.35 & -0.45 & -0.29 & -0.45 & -0.17 & -0.24 \\
\hline Self-employed & -0.14 & -0.26 & -0.11 & -0.19 & -0.43 & -0.42 & -0.32 & -0.32 & -0.48 & -0.58 & -0.42 & -0.48 & -0.37 & -0.52 & -0.19 & -0.29 \\
\hline$R^{2}$ & \multicolumn{2}{|c|}{0.030} & \multicolumn{2}{|c|}{0.038} & \multicolumn{2}{|c|}{0.053} & \multicolumn{2}{|c|}{0.075} & \multicolumn{2}{|c|}{0.105} & \multicolumn{2}{|c|}{0.118} & \multicolumn{2}{|c|}{0.152} & \multicolumn{2}{|c|}{0.274} \\
\hline Correlation TPI-TMI & \multicolumn{2}{|c|}{0.00} & \multicolumn{2}{|c|}{0.17} & \multicolumn{2}{|c|}{0.00} & \multicolumn{2}{|c|}{0.17} & \multicolumn{2}{|c|}{0.00} & \multicolumn{2}{|c|}{0.17} & 0. & & & \\
\hline Measures of Model fit & $\begin{array}{r}\mathrm{CFI}= \\
\mathrm{RMSE}\end{array}$ & $\begin{array}{l}.960 ; \\
=0.037\end{array}$ & $\begin{array}{r}\text { CFI = } \\
\text { RMSE }\end{array}$ & $\begin{array}{l}.973 ; \\
=0.028\end{array}$ & $\begin{array}{r}\mathrm{CFI}= \\
\mathrm{RMSE}\end{array}$ & $\begin{array}{l}.981 ; \\
=0.051\end{array}$ & $\begin{array}{r}\mathrm{CFI}= \\
\mathrm{RMSE}\end{array}$ & $\begin{array}{l}.987 ; \\
=0.036\end{array}$ & $\begin{array}{r}\mathrm{CFI}= \\
\mathrm{RMSE} f\end{array}$ & $\begin{array}{l}.931 ; \\
=0.050\end{array}$ & $\begin{array}{c}\mathrm{CFI}= \\
\mathrm{RMSE} A\end{array}$ & $\begin{array}{l}0.942 ; \\
=0.043\end{array}$ & $\begin{array}{c}\mathrm{CFI}= \\
\mathrm{RMSE} f\end{array}$ & $\begin{array}{l}0.926 ; \\
=0.056\end{array}$ & $\begin{array}{l}\mathrm{CFI}= \\
\text { RMSE }\end{array}$ & $\begin{array}{l}.978 ; \\
=0.028\end{array}$ \\
\hline
\end{tabular}

Statistically significant parameters $(\alpha=.05)$ on the basis of the unstandardised estimates are printed in bold.

Source: Swedish Welfare State Survey (2010).

Note: Structural equation modelling with WLSMV estimator. 
When it comes to the socio-economic variables effects on WSS, the following results are worth noting. For gender, the expected relationship that women should demonstrate higher WSS compared with men is only true for model 1C [Spending]. Gender differences are overall negligible as they are non-significant in models 1A [Finform], 1B [Taxwill] and 1D [Provider]. However, sector of employment behaves more in line with theory. In three models out of four (1B [Taxwill], 1C [Spending], 1D [Provider], private sector employees show lower levels of WSS compared with those employed in the public sector. Age shows a more mixed pattern across models. In model 1A [Finform], differences are non-significant. In model 1B [Taxwill], we can witness a curve linear effect; the young and the elderly are comparatively less willing to pay more in taxes in return for welfare compared with those in prime age. In models 1C [Spending] and 1D [Provider], the younger age groups demonstrate less WSS compared with older age groups. When it comes to class, theoretically expected and quite pronounced differences in WSS between self-employed and the service classes on the one hand, and the working classes on the other, can be observed across all four models, except perhaps for model 1A [Finform], where self-employed but not the service classes deviate from other classes.

To summarise the results so far, we find the expected positive relationships between TPI and WSS for three out of four models. For model 1C [Spending], the correlation is negative. The results are thus not totally coherent in terms of providing empirical support for, or against, the trust thesis. In our view, these results reflect the inconclusive and sometimes contradictory conclusions characterising previous empirical research. Turning to the socio-economic variables, the results for sector of employment and social class are generally in line with theoretical expectations. Public sector employees and working classes display higher WSS on average compared with private sector employees and the more privileged classes. Gender, in contrast, has an overall negligible impact on WSS. In relation to age, effects are non-uniform across WSS variables. However, on balance, it seems that young people are less supportive of the welfare state compared with other age groups.

Keeping these results in mind we now turn to the second, less restricted model within which the effects of TMI and TPI on WSS are simultaneously estimated. Considering the effects of TMI, the results are straightforward. Across all four models (2A-2D), the expected negative relationships between TMI and WSS are empirically supported. Higher TMI is associated with weaker support for taxation as a form of financing, less interest of paying additional taxes in return for welfare, opposing increased social spending, and more in favour of private welfare service provision. 
Moreover, a comparison of models 1 and 2 shows that model 2 reports higher values of explained variance and better model-fit statistics across all four WSS measures. ${ }^{9}$ The substantive implications of the overall better fit of model 2 compared with model 1 are the following. First, TMI has substantial negative effects on WSS. Second, when controlling for TMI, the expected positive effects of TPI on WSS increase. For example, when it comes to the provision of welfare [Provider], the beta coefficient for TPI in model $2 \mathrm{D}$ is 0.27 , compared with 0.21 in model $1 \mathrm{D}$. In a similar vein, the unexpected negative effect between TPI and social spending is weaker in model 2C compared with model 1C. Thus, when controlling for TMI, the effects of TPI on WSS appear more clear-cut. Why? The answer is the observed significant positive correlation between TPI and TMI. Somewhat crudely put, those trusting the state are also more likely to trust market actors and this tends to decrease their WSS to some extent. In a similar vein, those distrusting the state tend to distrust market actors, making them less inclined to abandon the welfare state in favour of the market. By controlling for TMI, the estimated effects of TPI on WSS are less biased. This finding underlines the importance of bringing in other institutional configurations that are seen as conceivable alternatives to the state for administrating social welfare, not the least in studies primarily interested in the link between TPI and support for state-organised welfare.

When comparing the effects of the socio-economic variables on WSS in models 1 and 2, the general message is that they are smaller in model 2. This is particularly true for social class and sector of employment; the two socio-economic variables having the most consistent effects on WSS. Therefore, it may be concluded that TMI is a non-negligible factor linking social position to welfare policy preferences.

The main results of the analysis are the following: (1) TMI has a robust negative effect on WSS; (2) the relationship between TPI and WSS becomes more distinct when controlling for TMI; and (3) TMI mediates the relationship between socio-economic variables and WSS.

\section{Conclusions}

When studying the links between institutional trust and support for stateorganised welfare, the main argument raised in this article is that research

${ }^{9}$ When comparing nested models, we judge a more restrictive model as preferable or "better", if both the decrease in CFI and the increase in RMSEA is smaller than 0.01 (Chen 2007; Davidov et al. 2011). We also compare models via $\chi^{2}$ difference tests, using the Mplus "DIFFTEST" appropriate to SEM applying the WLSMV estimator (results show $\mathrm{p}<0.000$ for all four model 1 versus model 2 comparisons) (Muthén and Muthén 2007, 367-378). 
should not just focus on public institutions; the analytical framework should be expanded by bringing in other institutional configurations that are perceived as conceivable alternatives to the state for organising and administrating social welfare. By applying the argument in the Swedish context, the analytical framework advanced in this article incorporated both public institutions and its main institutional alternative, the market.

The results of the empirical analysis supported the argument. Public support for state-organised welfare is clearly not only affected by citizens' conceptions of what the state can do but also by citizens' conceptions of what other institutional constructs - in this case market institutions cannot do. Three findings deserve to be underlined.

First, by comparing the role of trust in public and market institutions, empirical evidence suggests that perceptions of market performance are more important for structuring citizens' welfare policy preferences. In fact, although the relationship between TMI and support for state-organised welfare - an issue that has slipped under the radar of previous research turns out to be empirically robust in this paper, the link between TPI and WSS does not receive unequivocal empirical support. ${ }^{10}$

Second, the theoretically expected relationship between TPI and WSS becomes more pronounced once we bring in TMI into the analytical framework. The reason for this is that those trusting public institutions are also putting more trust in market institutions, making them less positive towards state-organized welfare. And conversely, those distrusting public institutions tend to distrust market institutions, making them less supportive of increasing the role of the market in the sphere of social welfare. By overlooking citizens' perceptions/experiences of market institutions, both in theory and empirical applications, previous research has probably underestimated the link between trust in public institutions and welfare state support

Third, although the role of market trust has not been explicitly subjected to analysis in previous research, we want to emphasise that the empirical results in this article fit very well with class-based theories on variations in welfare state development, effort and popular support (Korpi 1983; Esping-Andersen 1985; Korpi and Palme 2003; Svallfors 2006). Previous research on Sweden has shown that social class location typically structures welfare state preferences to a greater extent than more immediate citizen-state relationships, such as experiences and usage of

${ }^{10}$ When it comes to the measurements of the key concepts, TMI, TPI and WSS, the questions relating to TPI and WSS are much more similarly phrased compared with the TMI questions. In our view, this difference in the content of questions asked actually strengthens the overall conclusion of this paper that trust in market institutions is important in the formation of attitudes towards state-organised welfare. 
welfare services (Svallfors 1996). As this article demonstrates that trust in market institutions has a clear class hierarchical dimension, and that market trust also mediates the well-established link between class position and welfare policy preferences, the message of this article goes hand in hand with a basic idea in class-based welfare state theory: that welfare policy preferences are strongly dependent on the type and quantity of risks and resources that social groups bring to the market.

In our view, the theoretical design and the accompanying empirical evidence presented in this paper suggest that future research would benefit from integrating the concept of trust in market institutions into current theoretical frameworks on the relationships between institutional trust and popular welfare state support.

\section{Acknowledgements}

The authors are grateful to Stefan Svallfors, Peter John and two anonymous referees for valuable comments on previous versions of this manuscript. The authors are listed in alphabetical order and both have contributed equally to the article. Correspondence should be addressed to Arvid Lindh.

\section{References}

Beauducel A. and Herzberg P. Y. (2006) On the Performance of Maximum Likelihood Versus Means and Variance Adjusted Weight Least Squares Estimation in CFA. Structural Equation Modeling 13(2): 186-203.

Bergh A. (2007) Den kapitalistiska välfärdsstaten - om den svenska modellens historia och framtid. Stockholm: Norstedts.

Blomberg H. (1999) Do Cutbacks Pay off? Perceived Changes in the Standard of Municipal Services and Attitudes Towards Services Among Citizens and Municipal Decision Makers in Finland. International Journal of Social Welfare 8(3): 206-220.

Blomberg H., Kallio J., Kangas O., Kroll C. and Niemelä M. (2012) Attitudes Among High-Risk Groups. In Svallfors S. (ed.), Contested Welfare States. Welfare Attitudes in Europe and Beyond. Stanford: Stanford University Press, 58-80.

Blomqvist P. (2004) The Choice Revolution: Privatization of Swedish Welfare Services in the 1990s. Social Policy and Administration 38(2): 139-155.

Blomqvist P. and Rothstein B. (2000) Välfärdsstatens nya ansikte. Demokrati och marknadsreformer inom den offentliga sektorn. Stockholm: Agora.

Brown T. A. (2006) Confirmatory Factor Analysis. New York: Guilford.

Calzada I. and del Pino E. (2008) Perceived Efficacy and Citizen's Attitudes Toward Welfare State Reform. International Review of Administrative Sciences 74(4): 541-574.

Chen F. F. (2007) Sensitivity of Goodness of Fit Indices to Lack of Measurement Invariance. Psychological Bulletin 14(3): 464-504.

Crane A., Matten D. and Moon J. (2008) Corporations and Citizenship. Cambridge: Cambridge University Press.

Crouch C. (2011) The Strange Non-Death of Neoliberalism. Cambridge: Polity Press. 
Daly M. and Lewis J. (2000) The Concept of Social Care and the Analysis of Contemporary Welfare States. British Journal of Sociology 51(2): 281-298.

Davidov E., Datler G., Schmidt P. and Schwartz S. H. (2011) Testing the Invariance of Values in the Benelux Countries with the European Social Survey: Accounting for Ordinality. In Davidov, E. et al. (eds.), Cross-Cultural Analysis. New York: Routledge, 149-172.

Edlund J. (1999) Trust in Government and Welfare Regimes: Attitudes to Redistribution and Financial Cheating in the United States and Norway. European Journal of Political Research 35(3): 341-370.

- (2006) Trust in the Capability of the Welfare State and General Welfare State Support: Sweden 1997-2002. Acta Sociologica 49(4): 395-417.

Esping-Andersen G. (1990) The Three Worlds of Welfare Capitalism. Princeton: Princeton University Press.

Erikson R. and Goldthorpe J. H. (1992) The Constant Flux. Oxford: Clarendon.

Esping-Andersen G. (1985) Politics Against Markets: The Social Democratic Road to Power. Princeton: Princeton University Press.

- (1993) Changing Classes. London: Sage.

Ferrarini T., Nelson K., Palme J. and Sjöberg O. (2012) Sveriges socialförsäkringar i jämförande perspektiv. Uppsala Center for Labor studies. Working paper, 2012, 11.

Flora D. B. and Curran P. J. (2004) An Empirical Evaluation of Alternative Methods of Estimation for Confirmatory Factor Analysis with Ordinal Data. Psychological Methods 9(4): 466-491.

Gevers J., Gelissen J., Arts W. and Muffels R. (2000) Public Health Care in the Balance: Exploring Popular Support for Health Care Systems in the European Union. International Journal of Social Welfare 9(4): 285-300.

Hall P. A. and Soskice D. (eds.) (2001) Varieties of Capitalism. The Institutional Foundations of Comparative Advantage. Oxford: Oxford University Press.

Hartman L. (ed.) (2011) Konkurrensens konsekvenser. Vad händer med svensk välfärd? Stockholm: SNS Förlag.

Hernes H. (1987) Women and the Welfare State: The Transition from Private to Public Dependence. In Showstack Sassoon A. (ed.), Women and the State. London: Hutchinson, 72-92.

Hoel M. and Knutsen O. (1989) Social Class, Gender and Sector Employment as Political Cleavages in Scandinavia. Acta Sociologica 32(2): 181-201.

Hollingsworth J. R. and Boyer R. (1997) Contemporary Capitalism: The Embeddedness of Institutions. Cambridge/New York: Cambridge University Press.

Hu L. and Bentler P. M. (1999) Cutoff Criteria for Fit Indexes in Covariance Structure Analysis: Conventional Criteria Versus New Alternatives. Structural Equation Modelling 6(1): 1-55.

Holmberg S. and Weibull L. (2012) Förtroendet för staten. In Weibull L., Oscarson H. and Bergström A. (eds.), I framtidens skugga. Göteborg: SOM institute, 127-144.

Huber E. and Stephens J. D. (2001) Development and Crisis of the Welfare State. Chicago: University of Chicago Press.

Johansson Sevä I. (2010) Välfärdstatsundersökningen 2010 [The Welfare State Survey 2010]. Umeå: Umeå University.

Korpi W. (1983) The Democratic Class Struggle. London: Routledge and Kegan Paul.

Korpi W. and Palme J. (1998) The Paradox of Redistribution and Strategies of Equality: Welfare State Institutions, Inequality and Poverty in the Western Countries. American Sociological Review 63(5): 661-687. 
- (2003) New Politics and Class Politics in the Context of Austerity and Globalizsation: Welfare State Regress in 18 Countries, 1975-95. American Political Science Review 97(3): 425-446.

Kumlin S. (2004) The Personal and the Political. How Personal Welfare State Experiences Affect Political Trust and Ideology. Gordonsville: Palgrave Macmillan.

- (2007a) Overloaded or Undermined? European Welfare States in the Face of Performance Dissatisfaction”. In Svallfors S. (ed.), The Political Sociology of the Welfare State. Stanford: Stanford University Press, 80-116.

— (2007b) The welfare State: Values, Policy Preferences, and Performance evaluations. In Dalton R. J. and Klingeman H. D. (eds.), The Oxford Handbook of Political behavior. Oxford: Oxford University Press, 362-382.

Lipset S. M. and Schneider W. (1983) The Confidence Gap: Business, Labor, and Government in the Public Mind. New York: Free Press.

Marsh H. W., Hau K.-T. and Wen Z. (2004) In Search of Golden Rules: Comment on Hypothesis-Testing Approaches to Setting Cutoff Values for Fit Indexes and Dangers in Overgeneralizing $\mathrm{Hu}$ and Bentler's (1999) Findings. Structural Equation Modeling 11(3): 320-341.

Muthén B., du Toit S. H. C. and Spisic D. (1997) Robust inference using weighted least squares and quadratic estimating equations in latent variable modeling with categorical and continuous outcomes. Unpublished manuscript.

Muthén L. K. and Muthén B. O. (2007) Mplus User’s Guide, 5th ed. Los Angeles: Muthén \& Muthén.

Nye J., Zelikow P. and King D. (eds.) (1997) Why People Don't Trust Government. Cambridge: Harvard University Press.

Orloff A. S. (1993) Gender and the Social Rights of Citizenship: The Comparative Analysis of Gender Relations and Welfare States. American Sociological Review 58(3): 303-328.

Rauch D. (2007) Is There Really a Scandinavian Social Service Model? A Comparison of Childcare and Elderly care in Six European Countries. Acta Sociologica 50(3): 249-269.

Rose R. (1991) Is American Public Policy Exceptional? In Shafer B. E. (ed.), Is America Different? A New Look at American Exceptionalism. Oxford: Clarendon Press, 187-229.

Rothstein B. (1998) Just Institutions Matter. The Moral and Political Logic of the Universal Welfare State. Cambridge: Cambridge University Press.

Rothstein B. and Steinmo S. (eds.) (2002) Restructuring the Welfare State: Political Institutions and Policy Change. New York: Palgrave.

Schumacker R. E. and Lomax R. G. (2010) A Beginners Guide to Structural Equation Modeling. New York: Routledge.

Scruggs L. (2006) Generosity of Social Insurance 1971-2002. Oxford Review of Economic Policy 22(3): 349-364.

Sipilä J. (ed.) (1997) Social Care Services: The Key to the Scandinavian Welfare Model. Aldershot: Avebury.

Steinmo S. (1994) American Exceptionalism Reconsidered: Culture or Institutions? In Dodd L. and Jillson C. (eds.), The Dynamics of American Politics. Boulder, CO: Westview Press, 117-124.

Svallfors S. (1996) Välfärdsstatens moraliska ekonomi: välfärdsopinionen i 90-talets Sverige. Umeå: Borea.

— (2002) Political Trust and Support for the Welfare State: Unpacking a Supposed Relationship. In Rothstein, B. and Steinmo, S. (eds.), Restructuring the Welfare State: Political Institutions and Policy Change. New York: Palgrave, 184-203. 
— (2006) The Moral Economy of Class. Stanford: Stanford University Press.

(2012) Government Quality, Egalitarianism, and Attitudes to Taxes and Social Spending:

A European Comparison. European Political Science Review, doi:10.1017/ S175577391200015X.

Trydegård G-B. (2001) Välfärdstjänster till salu - privatisering och alternativa driftformer under 1990-talet. In Szebehely M. (ed.), Välfärdstjänster i omvandling, SOU 2001:52. Stockholm: Fritzes, 77-140.

Uslaner E. (2010) Trust and the Economic Crisis of 2008. Corporate Reputation Review 13(2): $110-123$.

Van Oorschot W. and Meuleman B. (2012) Welfare Performance and Welfare Support. In Svallfors S. (ed.), Contested Welfare States. Welfare Attitudes in Europe and Beyond. Stanford: Stanford University Press, 25-57.

Wright E. O. (2004) Beneficial Constraints: Beneficial for Whom? Socio-Economic Review 2(3): 407-414. 